\title{
Changes in intraruminal function of sheep when drinking saline water
}

\author{
By B. J. POTTER, D. J. WALKER AND W. W. FORREST* \\ Division of Nutritional Biochemistry, Commonwealth Scientific and \\ Industrial Research Organization, Kintore Avenue, Adelaide, \\ South Australia, 5000
}

(Received 31 December 1970-Accepted 28 fune 1971)

\begin{abstract}
I. A study was made of the changes in electrolyte concentrations and ruminal function which resulted from the provision of $I^{\prime} 3 \%$ sodium chloride solutions instead of fresh water to sheep consuming roughage rations in chaffed and in ground pelleted forms.

2. Significantly higher osmotic pressures were observed in the rumen fluid of the sheep drinking saline water, the change being especially marked when the ration was ground and pelleted.

3. Of the individual electrolytes measured, chloride showed a larger rise in concentration than did sodium plus potassium and it appeared that the sodium and chloride ions in the ingested saline water were differentially removed from the rumen.

4. Provision of $x \cdot 3 \% \mathrm{NaCl}$ solution in place of fresh water resulted in greater voluntary intakes of fluid and consequently in greater flows of fluid through the rumen.

5. Based upon measurements of deoxyribonucleic acid and polysaccharide, there appeared to be a tendency for the total microbial populations in the rumens of sheep drinking $\mathrm{I} \cdot 3 \% \mathrm{NaCl}$ solution to be smaller than for the sheep drinking fresh water.

6. The total metabolic activity of the rumen flora, measured calorimetrically, was not appreciably changed when saline water was drunk and the chaffed ration eaten, but was significantly reduced when the ration was ground and pelleted.

7. Adaptation of the rumen microflora to high concentrations of $\mathrm{NaCl}$ was demonstrated in animals accustomed to drinking $1 \cdot 3 \% \mathrm{NaCl}$ solution.
\end{abstract}

The tolerance of sheep for ingested drinking-water containing relatively high concentrations of dissolved salts is remarkably good (Peirce, 1957 ). The animals will survive for periods of 15 months or more drinking $\mathrm{I} \cdot 3 \%$ sodium chloride solution or mixtures of sodium chloride with other salts in solution making a total solute concentration of about $\mathrm{I} 3 \%$ (Peirce, $\mathrm{x}_{9} \mathrm{6}_{3}$ ). Productivity, in terms of body-weight and wool production, is unaffected by prolonged drinking of such salt solutions.

Studies by Potter (1961, 1963, 1966, 1968) have shown that there is an adaptive mechanism involving kidney function which allows the sheep to deal with large quantities of ingested or infused salt, and it has been suggested that this mechanism may be related to conditions within the rumen. Adaptation of the rumen flora was postulated by Peirce (1957) to account for the increased food consumption which often accompanied salt-water ingestion in sheep; and the absorption of sodium is stimulated by hypertonic conditions in the rumen according to Stacy \& Warner ( 1966$)$. von Engelhardt (1969) also suggested that the osmolality of the rumen may be important in the transport of ions and water in this organ, and Mitchell \& Moyle (1956) have indicated that micro-organisms may be greatly affected by changes in the osmotic pressure of their suspending medium.

\footnotetext{
* Present address: Australian Wine Research Institute, Waite Road, Urrbrae, South Australia, 5064.
} 
Since the rumen receives fluid almost immediately after it is ingested, it might be expected that changes in rumen function induced by salt-water intake could be important in the total response of the sheep to salt-water consumption.

EXPERIMENTAL

Animals

Six Merino ewes, with permanent rumen fistulas, were used throughout the experiments. Three animals had been accustomed to drinking $\mathrm{I} \cdot 3 \%$ sodium chloride for a period of 6-12 months. Whilst on experiment the animals were confined to metabolism cages.

\section{Rations}

Two rations were given, one consisting of $75 \%$ chaffed wheaten hay plus $25 \%$ chaffed luccrne hay, the other being ground pelleted lucerne hay. Each animal received a total of $\mathrm{I} \mathrm{kg}$ of the prescribed ration daily. When the rations were interchanged, a period of at least 2 weeks was allowed before further experiments were done.

\section{Experimental design}

The animals were studied in pairs, one animal drinking fresh water, the other $\mathrm{I} \cdot 3 \%$ sodium chloride solution. In each experiment one animal received the mixed chaff ration and the other received the ground pelleted lucerne.

Each animal was given $50 \mathrm{~g}$ of the appropriate ration at hourly intervals beginning at 10.00 hours until 17.00 hours when the remainder of the daily total was offered. At 08.00 hours on the day of each experiment $10 \mathrm{~g}$ of polyethylene glycol (PEG, mol. wt about 4000 ) in $50 \mathrm{ml}$ water were introduced into the rumen of each animal via the fistula. At 09.00 hours and half-hourly thereafter until $\mathrm{I} 7.00$ hours, approximately $5 \mathrm{ml}$ rumen fluid were withdrawn through a sampling tube covered with two layers of nylon bolting cloth, for PEG determination. At og.0o hours and hourly thereafter, Io $\mathrm{ml}$ samples of rumen fluid were withdrawn as above and added to $2 \mathrm{ml}$ of $10 \mathrm{~N}-$ $\mathrm{H}_{2} \mathrm{SO}_{4}$. These mixtures were placed in the refrigerator at $4^{\circ}$ for at least $3 \circ \mathrm{min}$ before the determination of polysaccharide and deoxyribonucleic acid (DNA).

Other samples of rumen fluid, taken at 09.00 hours and hourly thereafter, were stored in a refrigerator at $4^{\circ}$ for the determination of osmolality, sodium, potassium and chloride. This procedure was followed for 3 consecutive d, after which samples of whole rumen contents were collected, as described by Walker \& Forrest (1964), for calorimetric studies for a further $3-4 \mathrm{~d}$. These samples were withdrawn at 14.30 hours and a portion of each sample was set aside for determination of dry weight.

Upon completion of these observations, the rations were reversed and the entire experiment was repeated after the adaptation period of about 2 weeks mentioned above. No changes were made in the fluid drunk by the animals. 


\section{Chemical analyses}

Polyethylene glycol. Samples of rumen fluid of $\mathrm{I} \mathrm{ml}$ each were used in the turbidimetric method of Hydén (I955).

$D N A$. Acidified samples were centrifuged at $22000 \mathrm{~g}$ for $5 \mathrm{~min}$, the supernatant liquid was discarded, and the precipitate washed twice with I $\mathrm{N}-\mathrm{H}_{2} \mathrm{SO}_{4}$. The solids were then evenly suspended in $8 \mathrm{ml}$ water. Portions $(2 \mathrm{ml})$ of this suspension were then treated with $2 \mathrm{ml}$ of $\mathrm{I} \mathrm{N}$-perchloric acid and heated at $70^{\circ}$ for $25 \mathrm{~min}$. After removal of the insoluble residue by centrifuging, $\mathrm{I} \mathrm{ml}$ portions of the supernatant liquid were used for DNA determination by the method of Burton (1956), using calf thymus DNA standards.

Polysaccharide. Hexose polysaccharide was determined on I-in-10 or I-in-20 dilutions of the acidified, washed solids suspension prepared as described above. The method of Dische (1955) was used with pure glucose solutions as standards.

Osmolality, sodium, potassium and chloride. Rumen fluid samples were centrifuged at $10000 \mathrm{~g}$ for $10 \mathrm{~min}$ and the supernatant liquid was removed and stored at $4^{\circ}$ for analysis. Sodium and potassium were estimated by flame photometry using an EEL (Evans Electroselenium Ltd) flame photometer, and chloride by the method of Schales \& Schales (194I) modified by Domask \& Kobe (1952). Osmolalities were measured by freezing-point depression with a Fiske osmometer (Fiske Associates, Inc., Bethel, Conn., USA).

Dry-matter content. Samples of whole rumen contents were weighed and ovendried at $105^{\circ}$ for $24 \mathrm{~h}$.

Calorimetric determinations of rate of heat production. The method of Walker \& Forrest ( $\left.\mathrm{x}^{64} 4\right)$ was used. Samples of whole rumen contents $\left(25^{\circ} \mathrm{g}\right)$ were added to the calorimeter reaction vessel and the course of heat production from the degradation of the natural substrates was followed over a period of $2 \mathrm{~h}$. At the end of this period $5 \mathrm{ml}$ of a solution of $30 \% \mathrm{NaCl}$ were added to the rumen contents and the heat production was followed for a further $2 \mathrm{~h}$.

Volatile fatty acids. Volatile fatty acid (VFA) concentrations in the rumen were determined on rumen fluid samples acidified immediately after collection.

In vitro rates of VFA production were also determined on rumen contents taken for calorimetry. Samples of whole rumen contents ( $100 \mathrm{~g})$ were incubated at $39^{\circ}$ under gas phase of $60 \%$ nitrogen $+40 \%$ carbon dioxide. Portions $(5 \mathrm{~g})$ were withdrawn at $20 \mathrm{~min}$ intervals and $\mathrm{I} \mathrm{ml}$ of rumen fluid from each portion was used for VFA determination.

Total VFA were determined after acidification of the rumen fluid samples and steam distillation in the apparatus of Markham (I942). Volatile acids were titrated with o. OI N-NaOH.

\section{RESULTS}

Fluid intakes. The mean hourly fluid intakes of the sheep in each group are shown in Table I. The pelleted ration was associated with a greater fluid intake than the chaffed ration, the increases being significant in sheep drinking both fresh water 
$(P<0.001)$ and salt water $(P<0.05)$. When the animals were offered either the chaff or the pelleted ration, the fluid intakes were greater when salt-water was drunk. The differences were significant at the $1 \%$ level with the mixed chaff ration and at the $5 \%$ level with the ground pelleted diet.

Table I. Mean hourly intake by sheep of fresh water and $\mathrm{I} \cdot 3 \% \mathrm{NaCl}$ solution

\begin{tabular}{llcc} 
& \multicolumn{1}{c}{ Diet } & $\begin{array}{c}\text { Mean intake } \\
(\mathrm{ml})\end{array}$ & SE \\
Fresh water & Mixed chaff & $\mathrm{r} 44 \cdot 3$ & $\mathbf{2 2} \cdot 6$ \\
& Pellets & $292 \cdot \mathrm{I}$ & $\mathbf{2 3 \cdot 5}$ \\
$\mathrm{I} \cdot 3 \% \mathrm{NaCl}$ & Mixed chaff & $306 \cdot 0$ & $42 \cdot 3$ \\
& Pellets & $472 \cdot \mathrm{r}$ & $67 \cdot 8$
\end{tabular}

Table 2. Rates of flow of fluid through the rumen of sheep drinking fresh or saline water

\begin{tabular}{|c|c|c|c|c|}
\hline & \multicolumn{2}{|c|}{$\begin{array}{c}\text { Chaffed ration } \\
\text { (I4 determinations) }\end{array}$} & \multicolumn{2}{|c|}{$\begin{array}{c}\text { Pelleted ration } \\
\text { (9 determinations) }\end{array}$} \\
\hline & Fresh water & $\mathrm{I} \cdot 3 \% \mathrm{NaCl}$ & Fresh water & $\mathbf{I} \cdot 3 \% \mathrm{NaCl}$ \\
\hline $\begin{array}{l}\text { Calculated volume of } \\
\text { rumen contents (l) }\end{array}$ & 3.72 & $3 \cdot 67$ & $2 \cdot 65$ & $3 \cdot 27$ \\
\hline Mean dilution rate $\left(h^{-1}\right)$ & 0.137 & 0.183 & 0.155 & $0.21 I$ \\
\hline $\begin{array}{l}\text { Mean total flow of fluid } \\
\text { (l in } 7 \mathrm{~h})\end{array}$ & $3.57^{*}$ & $4 \cdot 70^{*}$ & $2.88 \dagger$ & $4.83 \dagger$ \\
\hline
\end{tabular}

Flow from the rumen. Rates of flow of fluid from the rumen, calculated from the rate of disappearance of PEG (Warner \& Stacy, I968), showed that drinking I.3\% $\mathrm{NaCl}$ increased flow from the rumen by an average of $32 \%$ in animals receiving the chaffed ration and by $68 \%$ in animals receiving the ground pelleted lucerne. In both instances the differences were significant at the $5 \%$ level, as indicated in Table 2.

Microbial population. Both DNA and polysaccharide concentrations in rumen fluid were used as indicators of the size of the microbial population. The validity of these measurements was checked using the ratio of crude protein $(\mathrm{N} \times 6 \cdot 25)$ to DNA in the samples of rumen fluid. In forty-five such determinations on material collected from animals given the chaffed ration, the protein: DNA ratio was $2 \times \cdot 5$ (range 16.9 24.8 ), which is close to values given for bacteria in general by Luria (r960). The chaffed ration itself had a crude protein:DNA ratio of $6_{3}$, indicating that rumen fluid samples from chaff-fed animals were relatively free from contamination with plant material. However, with samples taken from animals given the ground pelleted ration which had a protein:DNA ratio of 85 , the observed protein:DNA ratio was very variable and was usually above 30 , indicating a variable degree of contamination of the samples with food particles. For this reason only values for DNA and polysaccharide for samples from chaff-fed animals are given here.

Table 3 gives mean values for DNA and polysaccharide concentrations in rumen fluid from chaff-fed sheep. The average of the eight determinations done on each 
experiment was used as the value for that experiment in the statistical analysis. Thus, the standard errors quoted in Table 3 are based upon day-to-day variation between sheep. DNA concentration in the rumen fluid of sheep was lower when $1 \cdot 3 \% \mathrm{NaCl}$ was drunk instead of fresh water. However, variability was large and the differences were not statistically significant $(P<0 \cdot 1)$. For the polysaccharide concentrations the differences were significant $(P<0.05)$, the concentration being lower in the rumen fluid of animals drinking saline than in that of the controls.

Table 3. Mean daily $D N A$ and polysaccharide concentrations in rumen fluid from sheep given the chaffed ration and drinking either fresh or saline water

\begin{tabular}{|c|c|c|}
\hline & Fresh water & $\mathrm{I} \cdot 3 \% \mathrm{NaCl}$ \\
\hline DNA $+(\mu \mathrm{g} / \mathrm{ml})$ & $8 \pi \cdot 7$ & $54 \cdot 0$ \\
\hline SE of mean & $13 \cdot 8$ & $8 \cdot 8$ \\
\hline Polysaccharide $+(\mu \mathrm{g} / \mathrm{ml})$ & $7 \pm 6 *$ & $343^{*}$ \\
\hline SE of mean & I $52 \cdot 3$ & $25 \cdot 2$ \\
\hline
\end{tabular}

Table 4. The metabolic activity of the rumen microflora of sheep drinking fresh or saline water as judged by the dry-matter content of the rumen contents, their concentration of volatile fatty acids (VFA), and their rate of heat production

(Mean values with their standard errors)

\begin{tabular}{|c|c|c|c|c|}
\hline \multirow[b]{2}{*}{ Dry-matter content $(\%)$} & \multicolumn{2}{|c|}{ Chaff ration } & \multicolumn{2}{|c|}{ Pelleted ration } \\
\hline & $\begin{array}{l}\text { Fresh water } \\
\text { II } \cdot 8 \pm 0 \cdot 3\end{array}$ & $\begin{array}{l}\text { I.3\% NaCl } \\
\text { II } 4 \pm 0 \cdot 4\end{array}$ & $\begin{array}{l}\text { Fresh water } \\
13 \cdot 6 \pm 0.5 * * *\end{array}$ & $\begin{array}{l}1 \cdot 3 \% \mathrm{NaCl} \\
9 \cdot 6 \pm 0 \cdot 4^{* * *}\end{array}$ \\
\hline VFA concentration $(\mu \mathrm{mol} / \mathrm{ml})$ & $77 \cdot 2 \pm 0.9$ & $78 \cdot \mathrm{I} \pm \mathrm{I} \cdot \mathrm{I}$ & $103 \cdot 3 \pm I \cdot I * * *$ & $75 \cdot 1 \pm 1 \cdot 3 * * *$ \\
\hline $\begin{array}{l}\text { Rate of heat production of rumen } \\
\text { contents (cal } / \mathrm{kg} \mathrm{h})\end{array}$ & $488 \pm 25$ & $486 \pm 31$ & $591 \pm 29 * * *$ & $401 \pm 28 * * *$ \\
\hline $\begin{array}{l}\text { Rate of heat production calculated on } \\
\text { basis of I kg dry matter }(\mathrm{cal} / \mathrm{h})\end{array}$ & $4 \times 60$ & 4240 & 4340 & 4180 \\
\hline $\begin{array}{l}\text { Inhibition of heat production }(\%) \\
\text { when } \mathrm{Na}^{+} \text {concentration in the } \\
\text { rumen contents was increased by } \\
\text { I00 mmol/1 }\end{array}$ & $14 \cdot 0 \pm 1 \cdot 5 * * *$ & $5 \cdot 5 \pm x \cdot 3^{* * * *}$ & $13 \cdot 0 \pm \mathrm{I} \cdot 5 * * *$ & $5 \cdot 0 \pm x \cdot 2 * * *$ \\
\hline
\end{tabular}

*** Differences significant, $P<0.001$ by $t$ test.

Metabolic activity of the rumen population. For animals given the chaffed ration there were no significant differences between those drinking $\mathrm{I} \cdot 3 \% \mathrm{NaCl}$ and those drinking fresh water in the rate of heat production from the rumen contents, in the in vitro rate of VFA production or in the dry-matter content of the rumen digesta (Table 4 ). On the other hand, when the ground pelleted diet was given, highly significant differences were apparent in all three measurements. When heat production rates were expressed on the basis of calories per unit weight of dry matter in the digesta, the difference between the drinking regimens disappeared.

$\mathrm{NaCl}$ added to rumen contents to increase the concentration by $100 \mathrm{mmol} / 1$ caused a substantial fall in the rate of heat production in digesta taken from animals given fresh water. The inhibition of heat production in digesta from animals drinking 
$\mathrm{I} \cdot 3 \% \mathrm{NaCl}$ was much less $(P<0.00 \mathrm{r})$. The nature of the diet did not influence this finding (Table 4).

Osmotic effects. The osmolality of the rumen fluid increased significantly $(P<0.001)$ in all the sheep during the sampling period as indicated in T'able 5. The rate of increase was small in the sheep drinking fresh water, whereas in the sheep drinking the salt-water the increase was greater, particularly in those sheep that consumed the pelleted ration.

Sodium, potassium and chloride. In all the groups of sheep, except that in which pellets were consumed and salt-water was drunk, a reduction in the concentration of sodium in the rumen liquor occurred (Table 5 ). The reduction was small and not significant when chaffed diet was given, but was significant $(P<0 \cdot 001)$ in the sheep that drank fresh water and ate the pelleted ration. A significant increase of 3.9 mequiv. $/ 1 \mathrm{~h}$ $(P<0.001)$ was found to occur in the sheep given the pelleted diet and salt-water to drink.

Table 5. Rate of change with time of composition of rumen liquor samples taken from sheep drinking fresh and saline $(1 \cdot 3 \% \mathrm{NaCl})$ water during an $8 \mathrm{~h}$ period

\begin{tabular}{|c|c|c|c|}
\hline & Diet & $\begin{array}{l}\text { Fresh-water } \\
\text { sheep }\end{array}$ & $\begin{array}{l}\text { Salt-water } \\
\text { sheep }\end{array}$ \\
\hline Osmolality (m-osm/kg h) & $\begin{array}{l}\text { Mixed chaff } \\
\text { Pellets }\end{array}$ & $\begin{array}{l}2 \cdot 39(0.54) \\
3 \cdot 69(0.98)\end{array}$ & $\begin{array}{r}4.88(0.69) \\
I 2.80(0.89)\end{array}$ \\
\hline Sodium (mequiv./1 h) & $\begin{array}{l}\text { Mixed chaff } \\
\text { Pellets }\end{array}$ & $\begin{array}{l}-1.04(0.98) \mathrm{NS} \\
-3.27(0.46)\end{array}$ & $\begin{array}{c}-0.07(0.49) \mathrm{NS} \\
3.92(0.89)\end{array}$ \\
\hline Potassium (mequiv. $/ 1 \mathrm{~h}$ ) & $\begin{array}{l}\text { Mixed chaff } \\
\text { Pellets }\end{array}$ & $\begin{array}{l}1.75(0.17) \\
2.58(0.26)\end{array}$ & $\begin{array}{l}x \cdot 56(0.17) \\
\text { I. OI }(0.3 x)\end{array}$ \\
\hline Chloride (mequiv./l h) & $\begin{array}{l}\text { Mixed chaff } \\
\text { Pellets }\end{array}$ & $\begin{array}{l}0.81(0.08) \\
0.90(0.10)\end{array}$ & $\begin{array}{r}3.53(1.07) \\
x 0.10(1.34)\end{array}$ \\
\hline
\end{tabular}

The figures in parentheses are standard errors. NS, not significant; all other rates were significant at the $0.1 \%$ probability level.

Potassium values are shown in Table 5 and indicate that rumen potassium concentrations were significantly increased $(P<0.00 r)$ in all the groups, irrespective of the type of diet and fluid ingested. The results in Table 5 also show that the chloride concentrations were significantly increased during feeding $(P<0.00 \mathrm{r})$, but the increases were much greater in the sheep that drank salt-water and, of these two groups the chloride increase was greatest in the sheep that ate the pelleted diet.

\section{DISCUSSION}

The ingestion of saline water $(\mathrm{r} \cdot 3 \% \mathrm{NaCl})$ by sheep resulted in significant increases in osmotic pressure within the rumen, the increases being greater when the diet consisted of ground pelleted lucerne than when it consisted of chaffed hay. Unlike the control sheep drinking fresh water in which the rumen contents, in agreement with the reports of Kay ( 1963 ), von Engelhardt ( 1963$)$ and Warner \& Stacy ( 1965$)$, remained hypotonic compared with blood plasma, the rumen osmolality of the sheep drinking 
the salt-water became isotonic when the chaffed ration was eaten and hypertonic with the pelleted diet.

The changes in rumen osmotic pressure in the sheep drinking the salt-water might be expected to result from changes in the concentrations of electrolytes in the rumen, particularly in the concentrations of sodium and potassium (Warner \& Stacy, 1965). With the sheep drinking fresh water such a relationship seemed to exist, since the net effect of a slight reduction in sodium and increase in potassium would be to change the cationic concentration very little and this would cause only slight changes in osmotic pressure. This was found to be so in all the sheep receiving fresh water. With the sheep drinking salt-water, however, a similar relationship was not so evident, and instead a relationship appeared to exist between the rumen chloride levels and the osmotic pressure. This was demonstrated in the sheep drinking salt-water and eating the chaffed ration; while in these sheep the net (sodium + potassium) response in the rumen was not unlike that of the fresh-water group with the same diet, the rumen chloride concentrations and osmotic pressures were greater in the saline group. In view of the fact that the rumen chloride concentrations did not change appreciably in the fresh-water group of sheep and therefore agreed with the osmotic pressures, and that the hypertonicity of the rumen fluid of sheep drinking salt-water with the pelleted ration coincided with greatly increased chloride concentrations, it would appear that the osmotic pressure of the rumen may be related more directly to rumen chloride than to (sodium + potassium) changes. Any apparent anomaly in ionic equilibrium in the rumens of the sheep drinking the salt-water could be attributed no doubt to increased concentrations of ammonium ions which would influence the rumen osmotic pressure; this would agree with the observations of Warner \& Stacy ( $9_{9} 6_{5}$ ) that ammonium ions (with sodium and potassium) contribute to changes in rumen osmotic pressure, particularly after feeding. It also appears that, because the increases in chloride exceeded those in sodium (Table 5), the sodium and chloride ions of the ingested sodium chloride may be differentially removed from the rumen.

In terms of changes in rumen function, the effects observed were apparently related to the increased rate of passage of rumen fluid, which resulted from increased fluid intake, when saline was offered in place of fresh water. Additionally, there may have been an effect associated with increased osmolality which resulted in an increased flow-rate.

When the chaffed ration was consumed along with $\mathrm{I} \cdot 3 \% \mathrm{NaCl}$, there was a tendency for decreases to occur in the DNA and polysaccharide concentrations in the rumen fluid, indicating lowered populations of free-living organisms. However, there was no significant reduction in the dry-matter content of the whole rumen contents and no change in their metabolic activity as judged by calorimetric measurements. This indicates that with the chaffed ration only fluid flow, and not total digesta flow, was increased and that degradation of the solid feed particles was not significantly affected.

The situation was quite different when the ground pelleted ration was given. With that diet, ingestion of $\mathrm{I} \cdot 3 \% \mathrm{NaCl}$ led to a substantial fall in the dry-matter content of the whole rumen contents and this was associated with a $68 \%$ increase in fluid 
flow, showing increased rate of passage of the total digesta. The association of this with greatly reduced rates of VFA and heat production is indicative, in the absence of reliable DNA and polysaccharide values, of a greatly reduced microbial population. It is probable that the comminution of the feed to small particle size before feeding allowed a greater increase in total digesta flow when $1 \cdot 3 \% \mathrm{NaCl}$ was drunk than when the feed was given as a chaff.

The osmolality of rumen fluid in sheep drinking saline water, measured at the time of withdrawal of digesta for calorimetric studies, was $30-40 \mathrm{~m}-\mathrm{osm} / \mathrm{kg}$ higher than that in control sheep. This would not be expected to have an observable effect upon the rate of fermentation by the rumen organisms (Walker, I965). Thus, salt inhibition cannot be invoked to explain the lowered fermentation rates observed calorimetrically. It is, however, interesting to note the high degree of tolerance of the organisms from the saline-adapted sheep when a high salt load was applied during in vitro fermentation (Table 4). With the animals drinking fresh water, the salt concentration in certain areas of the rumen would have fallen for short periods to very low values upon ingestion of fluid, whereas when $\mathrm{r} \cdot 3 \% \mathrm{NaCl}$ was drunk, local concentrations of salts may have approached $220 \mathrm{mmol} / \mathrm{l}$ for a time. This difference was evidently sufficient to induce salt adaptation in the microbial population.

The utilization of a saline-drinking regimen for the purpose of obtaining a more rapid passage of digesta through the rumen presents a possible technique for altering the general metabolic and nutritional status of sheep. This would appear to be most likely if the feed were given in ground pelleted form and should result in a lowering of ruminal degradation of feed constituents which might be of advantage with highly digestible rations. Evidence for such changes has been presented by Walker, Potter $\&$ Jones (1971), who have shown a marked change in the proportions of fat, protein and water in animals given $\mathrm{r} \cdot 3 \% \mathrm{NaCl}$ instead of fresh water. Surprisingly however, the grinding and pelleting of the lucerne feed used did not modify the effect of saline beyond that observed when the lucerne was merely chaffed. These studies are being continued and extended.

The authors gratefully acknowledge the technical assistance given by Messrs G. L. Langsford and C. S. Chandler, and are indebted to Messrs W. B. Hall and R. Cunningham of the CSIRO Division of Mathematical Statistics for the statistical analyses of the experimental results.

\section{REFERENCES}

Burton, K. (1956). Biochem. \%. 62, 315.

Dische, Z. (1955). In Methods Biochemical Analysis Vol. 2, p. 313 [D. Glick, editor]. New York: Interscience Publishers Inc.

Domask, W. G. \& Kobe, K. A. (1952). Analyt. Chem. 24, 989 .

Hydén, S. (1955). LantbrHögsk. Annlr 22, I 39.

Kay, R. N. B. (1963). F. Dairy Res. 30, 261 .

Luria, S. E. (1960). In The Bacteria: a Treatise on Structure and Function Vol. I, p. I [I. C. Gunsalus and R. Y. Stanier, editors]. New York: Academic Press.

Markham, R. (1942). Biochem. F. 36, 790.

Mitchell, P. \& Moyle, J. (1956). Symp. Soc. gen. Microbiol. 6, 150. 
Peirce, A. W. (1957). Aust. 7. agric. Res, 8, 7 II.

Peirce, A. W. (1963). Aust. F. agric. Res. 14, 815.

Potter, B. J. (1961). Aust. F. agric. Res. 12, 440.

Potter, B. J. (1963). Aust. F. agric. Res. 14, 5 I8.

Potter, B. J. (1966). F. Physiol., Lond. 184, 605.

Potter, B. J. (1968). F. Physiol., Lond. x94, 435.

Schales, O. \& Schales, S. S. (1941). F. biol. Chem. 140, 879.

Stacy, B. D. \& Warner, A. C. I. (1966). Q. Il exp. Physiol. 51, 79.

von Engelhardt, W. (1963). Pflügers Arch. ges. Physiol. 278, г 52.

von Engelhardt, W. (1969). Zentbl. VetMed. A. r6, 597.

Walker, D. J. (r965). In Physiology of Digestion in the Ruminant p. 296 [R. W. Dougherty, editor].

Washington, D.C.: Butterworths Inc.

Walker, D. J. \& Forrest, W. W. (1964). Aust. \%. agric. Res. 15, 299.

Walker, D. J., Potter, B. J. \& Jones, G. B. (1971). Aust. 7. exp. Agric. Anim. Husb. Ix, 14.

Warner, A. C. I. \& Stacy, B. D. (1965). O. Fl exp. Physiol. 50, I6y.

Warner, A. C. I. \& Stacy, B. D. (Ig68). Br. F. Nutr. 22, 369. 